Article

\title{
Ecotoxicological Assessment of a Glyphosate-Based Herbicide in Cover Plants: Medicago sativa L. as a Model Species
}

\author{
Beatriz Fernandes ${ }^{1,2, \dagger}$, Cristiano Soares ${ }^{1,3, *,+} \mathbb{C}$, Cláudia Braga ${ }^{1}$, Ana Rebotim ${ }^{1}$, Rafael Ferreira ${ }^{1}$, \\ Joana Ferreira ${ }^{1}$, Fernanda Fidalgo ${ }^{1,3}\left(\mathbb{D}\right.$, Ruth Pereira ${ }^{1,3, *}$ ) and Anabela Cachada ${ }^{1,4}(\mathbb{C}$ \\ 1 Department of Biology, Faculty of Sciences of the University of Porto, Rua do Campo Alegre, $\mathrm{s} / \mathrm{n}$, \\ 4169-007 Porto, Portugal; up201503352@fc.up.pt (B.F.); 10180059@ess.ipp.pt (C.B.); \\ up201603230@fc.up.pt (A.R.); up201604298@fc.up.pt (R.F.); up201604044@fc.up.pt (J.F.); \\ ffidalgo@fc.up.pt (F.F.); acachada@fc.up.pt (A.C.) \\ 2 Department of Geosciences, Environment and Spatial Plannings, Faculty of Sciences of the University of \\ Porto, Rua do Campo Alegre, s/n, 4169-007 Porto, Portugal \\ 3 GreenUPORTO-Sustainable Agrifood Production Research Centre, Campus de Vairão, Rua da Agrária 747, \\ 4485-646 Vairão, Portugal \\ 4 CIIMAR, Novo Edifício do Terminal de Cruzeiros do Porto de Leixões, Avenida General Norton de Matos, \\ S/N, 4450-208 Matosinhos, Portugal \\ * Correspondence: cfsoares@fc.up.pt (C.S.); ruth.pereira@fc.up.pt (R.P.) \\ + These authors contributed equally to this work and, therefore, both should be considered as first co-authors.
}

Received: 26 May 2020; Accepted: 23 July 2020; Published: 24 July 2020

Featured Application: This study is a starting-point to better understand the effects of GLY-contaminated soil on non-target plants, since very little is known about this subject.

\begin{abstract}
Despite the several innovations that have been incorporated in agriculture, the use of herbicides, especially glyphosate (GLY), is still the major tool for weed control. Although this herbicide has a notable worldwide representation, concerns about its environmental safety were recently raised, with a lot of divergence between studies on its non-target toxicity. Therefore, it is of utmost importance to understand the risks of this herbicide to non-target plants, including cover crop species, which have a crucial role in maintaining agroecosystems functions and in preventing soil erosion. Thus, this work aims to evaluate the growth and physiological responses of a cover plant species (Medicago sativa L.) exposed to increasing concentrations of a GLY-based herbicide (GBH), particularly focusing on the oxidative metabolism. The growth of roots and shoots was affected, being this effect accompanied by a rise of lipid peroxidation, suggesting the occurrence of oxidative stress, and by an activation of the antioxidant (AOX) system. Indeed, the results showed that adverse effects are visible at active ingredient concentrations of $8.0 \mathrm{mg} \mathrm{kg}^{-1}$, with the lowest $\mathrm{EC}_{50}$ being $12 \mathrm{mg} \mathrm{kg}^{-1}$, showing that GBH-contaminated soils may pose a risk to the survival of non-target plants in the most contaminated areas. Overall, these findings proved that GBH greatly impairs the growth of a non-target plant, strengthening the need of additional studies to unravel the real risks associated with the over usage of this pesticide, since there is an evident lack of studies performed with contaminated soils.
\end{abstract}

Keywords: herbicides; alfalfa; oxidative stress; antioxidant system; reactive oxygen species

\section{Introduction}

Plant protection products, also referred to as pesticides, are widely used in agriculture in order to improve productivity, prevent crop loss or yield reduction, and control disease vectors or agents. 
However, it is known that only a small portion of the applied pesticides reach the target pests, while the remainder will end up in soil or will have the potential to move to other environmental compartments, including ground and surface waters [1,2]. Nevertheless, the mobility of these contaminants in the environment depends on several biotic and abiotic variables, and their physical-chemical properties. Thus, depending on the persistence of each substance, soil contamination can occur, thereby affecting soil quality, compromising its ability to perform its functions and leading to an irreversible degradation of this non-renewable resource [3-7]. For this reason, concerns about the use of pesticides are increasing, and the most controversial at the moment is probably glyphosate (GLY), a post-emergence and systemic herbicide of broad spectrum (non-selective). Applied to the foliage of weeds, GLY is absorbed by the leaves and is rapidly translocated in the plant through the phloem, particularly accumulating in meristems (root and shoot apex). Right after its discovery in the 1970s, GLY quickly became the most applied herbicide worldwide and, in 2014, the volume applied was sufficient to treat between $22 \%$ and $30 \%$ of globally cultivated cropland [8]. Despite its great efficiency, several concerns about this herbicide were recently raised, related to the divergence between scientific studies regarding its toxicity to non-target organisms $[9,10]$. Another factor that may turn difficult to evaluate the real impacts of GLY on the environment is that GLY commercial formulations not only contain GLY, but also substances such as polyethoxylated amine (POEA) surfactants [11]. It is known that the first generation of POEA surfactants present in Roundup ${ }^{\circledR}$ were markedly more toxic than GLY, but since the mid-1990s, these compounds were progressively replaced by other POEA surfactants, ethoxylated etheramines, which exhibit lower non-target toxic effects [11]. However, the composition of non-active ingredients in a GLY-based herbicide (GBH) is not fully known, and while a recent study pointed to a lower toxicity for earthworms of the GBH compared with the active ingredient (a.i.) itself, Pochron et al. [9] in another study concluded the opposite regarding Dimorphandra wilsonii seed germination [12]. Thus, GLY can be considered an old pesticide, but an emergent problem.

In areas in which high extensions of land are dedicated to intensive agriculture, the dispersion of GLY in the environment can be a serious problem of diffuse contamination, particularly due to its tendency to adsorb to solid particles $[13,14]$. Depending on climactic conditions (especially temperature and humidity), the removal of GLY from soils can be reduced, resulting in its accumulation [15]. This accumulation and dispersion through the environment, due to its non-selectivity [16,17], can cause damage to plants that are not targeted, affecting a great number of species that account both directly and indirectly for soil biodiversity. From the available data, it was suggested that GLY negative effects on plant growth and development substantially exceed the effects triggered by its mode of action as it can induce several metabolic and physiological disorders, favoring the occurrence of oxidative stress as an indirect consequence [18]. Indeed, when plants are exposed to stress factors, such as soil contamination, oxidative stress occurs due to an overproduction of reactive oxygen species (ROS) $[19,20]$. Therefore, given their higher sensibility, ROS, along with oxidative stress parameters (e.g., lipid peroxidation), can be used as exposure biomarkers, allowing an early warning and sensitive evaluation of plant physiological status, representing a potential tool to phytotoxicity studies [21]. Although ROS are important signaling agents, high levels of these compounds can easily become phytotoxic, damaging proteins, lipids, carbohydrates, and nucleic acids. By influencing the cellular gene expression pattern, ROS are involved in many processes, such as growth, cell cycle, abiotic stress responses, pathogen defense and systemic signaling and development. Thus, in order to maintain the redox homeostasis of the cell, plants possess a powerful antioxidant (AOX) system, composed of both enzymatic and non-enzymatic mechanisms [22]. It is the joint action of these players that prevent the occurrence of redox disorders in the cell, by directly neutralizing the toxic effects of ROS and/or by preventing their overaccumulation. However, depending on the plant species, the magnitude of stress and the exposure period, the AOX system may not be able to efficiently counteract ROS-induced toxicity, leading to the establishment of an oxidative stress condition [20].

One group of plants that is particularly exposed to GLY contamination is cover plants, since they can be sown a few months after the herbicide application, during the off-season. In crops, such as vines, 
they can be sown between the lines and left as a green cover. They are of extreme importance to the management of soil erosion, fertility and quality, as well as crop yield [23,24]. Indeed, the European Commission established that the maintenance of permanent grassland areas is one of the actions that every EU country and all farmers must put in place, if they want to be rewarded for the protection of natural resources [25]. Thus, by affecting cover plants, GLY may jeopardize the balance of the ecosystem in which they are inserted. An example of a cover plant is Medicago sativa L., commonly known as alfalfa, a perennial leguminous, belonging to the family Fabaceae and subfamily Faboideae, well known by its ability to improve both soils' structure and biochemical activity [26]. This cover crop has the potential to establish symbiotic relations with $\mathrm{N}_{2}$-fixing bacteria, thus increasing its growth and development, while contributing for the enrichment of soils with nitrogen compounds [27,28].

Since little is known about the potential phytotoxicity of GLY contaminated soil, particularly in non-target species, the aim of this work is to unravel the effects of soil contamination by this herbicide on the growth and redox homeostasis of a cover plant species, Medicago sativa. By combining biometrical and biochemical approaches, this study will focus not only on the effects of a GBH (GLY-based herbicide) on the development and growth performance of M. sativa, but also on the assessment that whether its toxicity is mediated by the occurrence of oxidative stress.

\section{Materials and Methods}

\subsection{Preparation of the Artificial Soil}

The substrate used in this work consisted in an artificial soil composed of $70 \%(\mathrm{~m} / \mathrm{m})$ sand, $20 \%(\mathrm{~m} / \mathrm{m})$ kaolin and $10 \%(\mathrm{~m} / \mathrm{m})$ peat [29]. The $\mathrm{pH}_{\mathrm{KCl}}$ of the soil $(1: 5 \mathrm{~m} / \mathrm{v})$ was adjusted to $6.0 \pm 0.5$ by the addition of calcium carbonate $\left(\mathrm{CaCO}_{3}\right)$, whenever necessary.

\subsection{Glyphosate (GLY) Concentrations Tested}

The herbicide Roundup UltraMax ${ }^{\circledR}$ (Bayer, Germany), acquired from a local supplier, was used in this study. From the commercial formulation ( $360 \mathrm{~g} \mathrm{~L}^{-1} \mathrm{GLY}$ as potassium salt), a stock solution was prepared and a series of sequential doses of the GBH was applied, ranging from 0 to $40 \mathrm{mg} \mathrm{kg}^{-1}$ of the active ingredient (a.i.), with a dilution factor of 1.5, giving rise to the following concentrations: 40 ; 27; $18 ; 12 ; 8.0 \mathrm{mg} \mathrm{kg}^{-1}$, which were tested together with a GBH-free control (CTL). The concentrations were chosen based on the results of a previous published work conducted by the team [30,31], and reflect not only data concerning GLY contamination levels in soils, but also the recommended applied doses for agricultural practices.

\subsection{Plant Material and Growth Conditions}

The seedling emergence and seedling growth test, performed according to the OECD (Organisation for Economic Co-operation and Development) protocol for terrestrial plants [3], was carried out in plastic pots containing $200 \mathrm{~g}$ of artificial soil, to which the solutions with the desired GLY concentrations were added. Maintenance of soil moisture was ensured by the presence of a pot with distilled water placed at the base of the soil pots with soil, and by using a cotton rope to ensure the capillarity rise of the water. Twenty seeds of Medicago sativa var. Dimitra, acquired from Flora Lusitana Lda (Cantanhede, Portugal), were placed in each pot, after sterilization with 70\% (v/v) ethanol $(7 \mathrm{~min})$ and $20 \%(v / v)$ commercial bleach ( $5 \%$ active chloride; $7 \mathrm{~min}$ ), followed by washing with deionized water. To ensure the availability of nutrients, a commercial fertilizer (EcoGrow, NPK 3-6-7) was added at the start of the test. A negative control (CTL; absence of contaminant) was also prepared, obtaining a total of 24 pots (four replicates for each treatment). The assay began when $50 \%$ of the seeds from the CTL germinated. In each pot, only eight plants were kept, avoiding intraspecific competition. The plants germinated and grew in a growth chamber with controlled temperature $\left(21^{\circ} \mathrm{C}\right)$, photoperiod $(16 \mathrm{~h} \mathrm{light} / 8 \mathrm{~h}$ dark $)$ and photosynthetically active radiation $\left(120 \mu \mathrm{mol} \mathrm{m}^{-2} \mathrm{~s}^{-1}\right)$. After 21 days of growth, plants from each replicate were collected, used for the estimation of biometric parameters and then shoots were frozen 
in liquid nitrogen and stored at $-80^{\circ} \mathrm{C}$ until analyses. The assay lasted 21 days post-germination, since, at this point, $M$. sativa individuals are in their vegetative phase before flowering. Moreover, this period did not conditionate the acquisition of fresh material for the biochemical analyses.

\subsection{Analysis of Biometric Indicators}

The biometric analysis was performed as described in the OECD protocol for seedling emergence and seedling growth test [32]. Eight plants from each replicate of every experimental group were used. After root and shoot separation, root length, and shoot height were measured, and the fresh masses of roots and shoots were registered.

\subsection{Determination of Physiological Endpoints}

Total chlorophylls $(\mathrm{a}+\mathrm{b})$ and carotenoids were extracted in $80 \%(v / v)$ acetone and quantified by spectrophotometry, as described by Lichetenthaler [33]. The absorbances at 470, 647, and $663 \mathrm{~nm}$ were recorded, and the results obtained were expressed in $\mathrm{mg} \mathrm{g}^{-1}$ fresh weigh ( $\mathrm{fw}$ ).

Total soluble protein content and glutamine synthetase (GS; EC 6.3.1.2) were extracted by homogenizing, on ice, frozen shoot samples in an extraction buffer, followed by a centrifugation at $4{ }^{\circ} \mathrm{C}$ for $20 \mathrm{~min}$ and $15,000 \times \mathrm{g}$. Afterwards, extracts were used to quantify the total soluble protein [34] and to determine GS activity by the transferase assay [35] by recording the absorbance at $500 \mathrm{~nm}$. GS activity was calculated and expressed as nkat $\mathrm{mg}^{-1}$ protein.

\subsection{Quantifiaction of Oxidative Stress Biomarkers}

The assessment of lipid peroxidation (LP) was performed as described by Heath and Packer [36], by the quantification of malondialdehyde (MDA). Briefly, plant samples were homogenized in $0.1 \%$ $(w / v)$ trichloroacetic acid (TCA) and subsequently centrifuged (5 min; 10,000 $\times g)$. Afterwards, the extracts were incubated with a mixture of $0.5 \%(w / v)$ thiobarbituric acid (TBA) and $20 \%(w / v)$ TCA for $30 \mathrm{~min}$ at $95^{\circ} \mathrm{C}$. At the end, the absorbances of each sample was read at 532 and $600 \mathrm{~nm}$. After this step, the absorbance values of $532 \mathrm{~nm}$ were subtracted from those obtained at $600 \mathrm{~nm}$ to eliminate the effects of unspecific turbidity. The molar extinction coefficient $\left(\varepsilon=155 \mathrm{mM}^{-1} \mathrm{~cm}^{-1}\right)$ was used to calculate MDA levels and the results were expressed as $\mathrm{nmol} \mathrm{g}^{-1} \mathrm{fw}$.

The determination of hydrogen peroxide $\left(\mathrm{H}_{2} \mathrm{O}_{2}\right)$ was performed according to the procedure described by Jana and Choudhuri [37]. Upon the homogenization of shoot aliquots in $0.1 \%(w / v)$, TCA and centrifugation $(6000 \times g ; 25 \mathrm{~min})$, the obtained plant extracts were combined with a mixture containing $0.1 \%(w / v) \mathrm{TiSO}_{4}$ in $20 \%(v / v) \mathrm{H}_{2} \mathrm{SO}_{4}$. Finally, the absorbance at $410 \mathrm{~nm}$ of each sample was recorded and the $\mathrm{H}_{2} \mathrm{O}_{2}$ levels were determined using the molar extinction coefficient of $0.28 \mu \mathrm{M}^{-1} \mathrm{~cm}^{-1}$. Results were expressed in $\mathrm{nmol} \mathrm{g}^{-1} \mathrm{fw}$.

\subsection{Analysis of the AOX Response}

In order to determine the total antioxidant capacity (TAC) and the total phenolics, the procedure described by Zafar et al. [38] was followed. Firstly, frozen shoot samples were extracted in $80 \%$ $(v / v)$ methanol followed by a centrifugation at $2500 \times \mathrm{g}$, for $10 \mathrm{~min}$. Regarding TAC, upon dilution of the extracts (1:5), these were mixed with a reaction solution $\left(0.6 \mathrm{M} \mathrm{H}_{2} \mathrm{SO}_{4}, 4 \mathrm{mM}\right.$ ammonium molybdate and $28 \mathrm{mM}$ sodium phosphate), incubated at $95^{\circ} \mathrm{C}$ for $90 \mathrm{~min}$, and cooled on ice. After that, the absorbance was read at $695 \mathrm{~nm}$. TAC levels were obtained from a calibration curve obtained with dilutions of a standard solution of ascorbic acid (AsA) and the results expressed in mg equivalents of $\mathrm{AsA}^{-1} \mathrm{fw}$. Concerning phenolics, their quantification was performed by a colorimetric assay using the Folin-Ciocalteu reagent. Absorbance was registered at $725 \mathrm{~nm}$ and total phenols concentrations were calculated from a calibration curve, prepared with dilutions of a gallic acid solution. The results were expressed in $\mathrm{mg}$ of gallic acid $\mathrm{g}^{-1} \mathrm{fw}$.

The extraction and quantification of proline (Pro) was performed as previously described by Bates et al. [39], using the ninhydrin-based colorimetric assay. Samples were homogenized in 3\% (w/v) 
sulphosalicylic acid and centrifuged $(500 \times g ; 10 \mathrm{~min})$. Then, the extracts were incubated, under acid conditions, with a ninhydrin solution for $1 \mathrm{~h}$ at $96^{\circ} \mathrm{C}$. At the end, the absorbance of each sample was read at $520 \mathrm{~nm}$ and Pro content was obtained from a calibration curve obtained with known Pro concentrations, and the results were expressed as $\mu \mathrm{g} \mathrm{g}^{-1} \mathrm{fw}$.

\subsection{Statistical Analyses}

All endpoints were evaluated using at least three replicates per treatment and the results were expressed as mean \pm standard deviation (SD). The effects of the herbicide on the parameters previously mentioned were evaluated using one-way analysis of variance (ANOVA) after checking the homogeneity of variances by the Levene Test. Whenever $p \leq 0.05$, the post-hoc Dunnett's test was used to compare the mean of each group with the CTL. The $\mathrm{EC}_{50}$ (concentration of GLY expected to have an effect in $50 \%$ of test organisms) and the corresponding 95\% confidence limits (95\% CL) for the biometric parameters, were estimated with a non-linear least-squares regression adjustment. All statistical procedures were performed in GraphPad Prism 8.

\section{Results}

\subsection{Biometric Parameters of M. sativa}

As shown in Figures 1 and 2, the application of a GBH had a negative impact in both root and shoot length and biomass. By analyzing Figure 1a, it is possible to notice that there was a significant decrease in root length $(F(5,16)=106.8 ; p \leq 0.05)$ for concentrations above the second lowest, with a monotonic dose-response relationship. Between 12 and $18 \mathrm{mg} \mathrm{kg}^{-1}$ of the a.i. there was a drastic reduction in root length-the inhibition values rose from $27 \%$ to $68 \%$ comparatively to the CTL group, in which the $\mathrm{EC}_{50}$ was estimated to be $16 \mathrm{mg} \mathrm{kg}^{-1}$ (95\% CL: 14-19). Regarding shoot length, despite the observed decrease as the concentration increased, significant differences $(F(5,16)=36.21 ; p \leq 0.05)$ were only recorded when plants were exposed to the highest doses of GBH $\left(18,26\right.$ and $40 \mathrm{mg} \mathrm{kg}^{-1}$ of the a.i.), with inhibition values up to $64 \%$ in relation to the CTL. Nevertheless, a similar $\mathrm{EC}_{50}$ was estimated (16 $\mathrm{mg} \mathrm{kg}^{-1}$ of the a.i.; $95 \%$ CL: $\left.14-22\right)$.

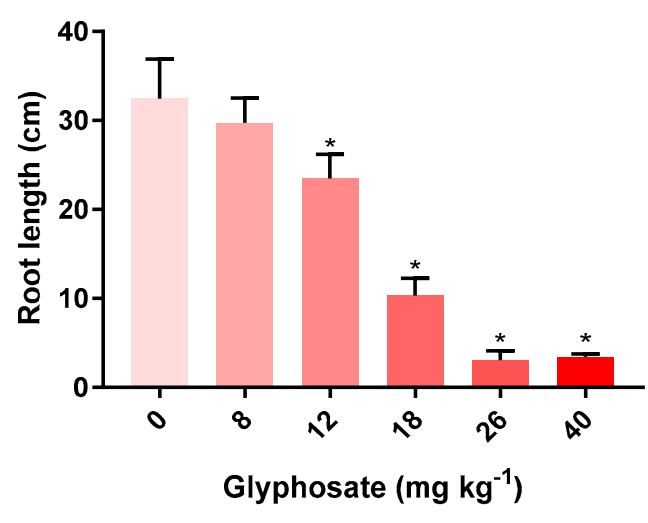

(a)

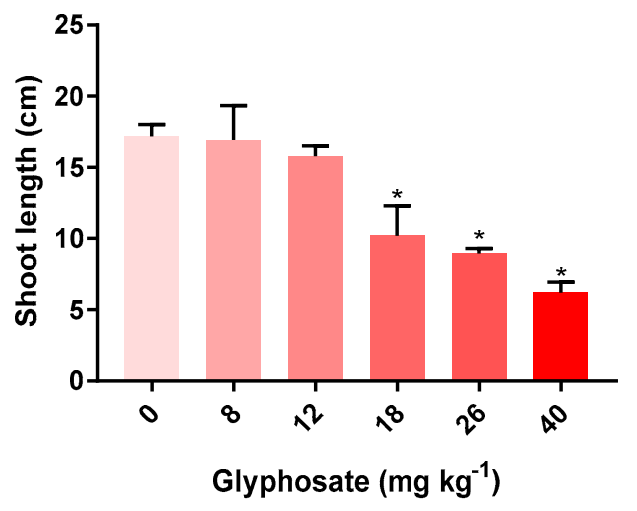

(b)

Figure 1. Average root (a) and shoot (b) lengths of $M$. sativa plants, 21 days after exposure to different concentrations of glyphosate (GLY). Error bars correspond to the standard deviation. Statistically significant differences compared to the control (CTL; no GLY), considering $p \leq 0.05$, are marked with a * above bars.

Regarding fresh biomass (Figure 2), both roots and shoots were affected by GBH exposure in a concentration-dependent manner. Despite both organs exhibiting the same global trend, the results point towards a higher sensitivity of shoots when compared with roots. In fact, while in shoots, all concentrations are statistically different from the $\operatorname{CTL}(\mathrm{F}(5,15)=92.02 ; p \leq 0.05)$-reaching inhibition 
values ranging from $36 \%$ to $88 \%$, in roots biomass-significant differences $(\mathrm{F}(5,16)=16.02 ; p \leq 0.05)$ were only detected upon exposure to a.i. concentrations of 18,26 and $40 \mathrm{mg} \mathrm{kg}^{-1}$, with reductions of about 62,79 and $90 \%$, respectively. The highest effects observed in shoots are translated into differences in the $\mathrm{EC}_{50}$ values obtained. For root fresh biomass, the estimated a.i. concentration was $15 \mathrm{mg} \mathrm{kg}^{-1}$ (95\% CL: 12-22), whereas for the shoot fresh biomass it was $12 \mathrm{mg} \mathrm{kg}^{-1}$ (it was only possible to calculate the lower limit of the CL, which was 8.5).

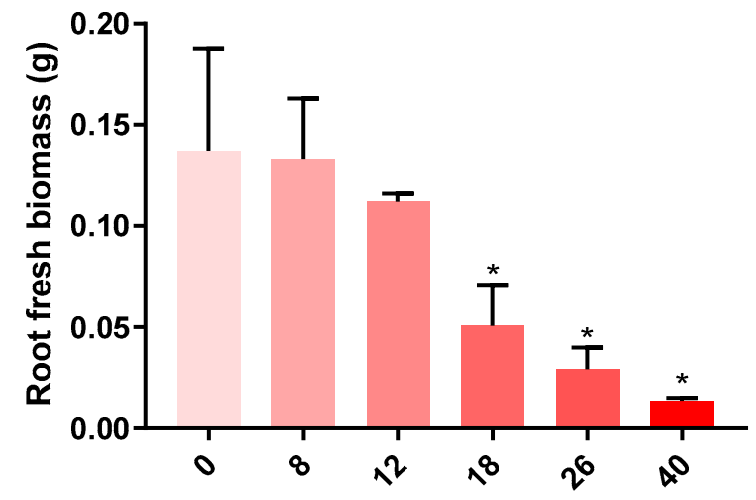

Glyphosate $\left(\mathrm{mg} \mathrm{kg}^{-1}\right)$

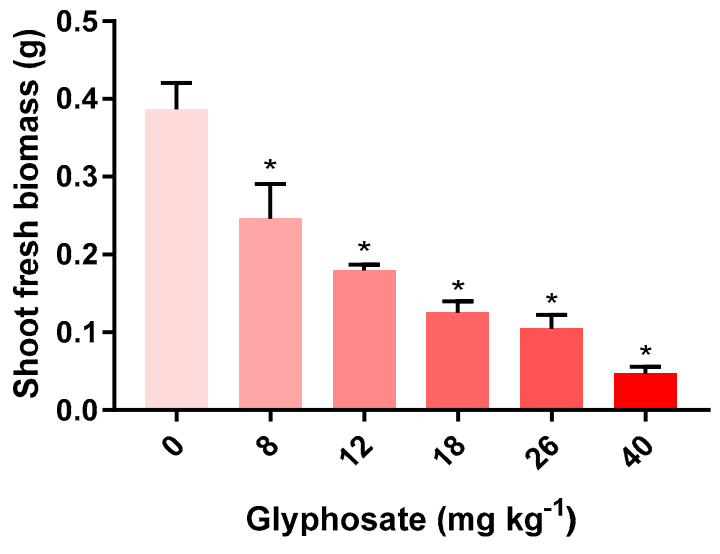

(b)

Figure 2. Average biomass of roots (a) and shoots (b) of $M$. sativa plants, 21 days after exposure to increased concentrations of GLY. Error bars correspond to the standard deviation. Statistically significant differences compared to the CTL, considering $p \leq 0.05$, are marked with a ${ }^{*}$ above bars.

\subsection{Physiological Parameters on M. sativa}

For the photosynthetic pigments, the behavior was similar for both total chlorophylls and carotenoids (Figure 3a,b, respectively), as no significant statistical differences were registered among treatments and the CTL-F $(5,12)=2.072 ; p>0.05$ for total chlorophylls and $\mathrm{F}(5,8)=2.920 ; p>0.05$ for carotenoids.

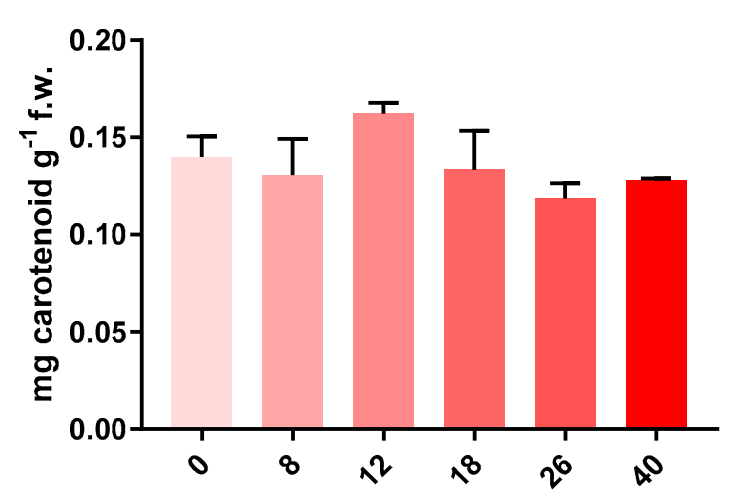

Glyphosate (mg kg-1)

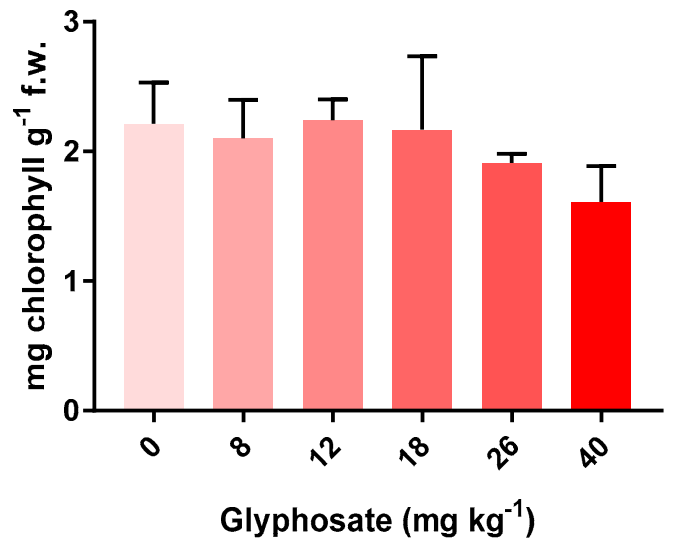

(b)

(a)

Figure 3. Cont. 


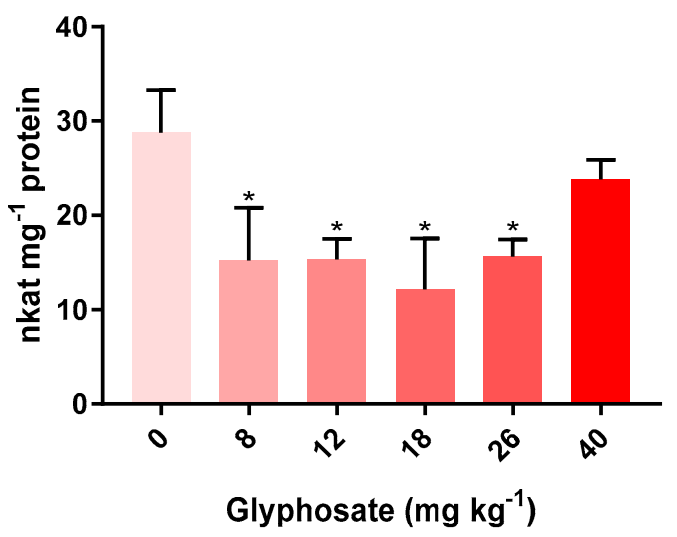

(c)

Figure 3. Average concentrations of carotenoid (a) and chlorophyll (b) and glutamine synthetase (GS) activity levels (c) in shoots of M. sativa plants 21 days after exposure to increased concentrations of GLY. Error bars correspond to the standard deviation. Statistically significant differences compared to the CTL, considering $p \leq 0.05$, are marked with a * above bars.

GS levels (Figure 3c) showed a different pattern from that of the photosynthetic pigments. Comparatively to the CTL, all GBH concentrations induced a significant reduction in GS activity levels $(F(5,12)=7.851 ; p \leq 0.05)$. As can be observed in Figure $3 c$, when plants were exposed to a.i. concentrations between 8 and $26 \mathrm{mg} \mathrm{kg}^{-1}$, decreases of around $50 \%$ were found in comparison with the CTL. Curiously, upon exposure to the highest concentration, GS levels became closer those registered for the CTL.

\subsection{Oxidative Stress Biomarkers on M. sativa}

The behaviors of the analyzed oxidative stress biomarkers, $\mathrm{H}_{2} \mathrm{O}_{2}$ and LP, are shown in Figure 4 . In general, $\mathrm{H}_{2} \mathrm{O}_{2}$ levels rose along with the increase in $\mathrm{GBH}$ concentration (Figure 4a). However, significant differences $(\mathrm{F}(5,11)=6.294 ; p \leq 0.05)$ were only observed for concentrations higher than $12 \mathrm{mg} \mathrm{kg}^{-1}$, compared to the CTL. A similar behavior was also observed for LP with MDA levels increasing in a concentration-dependent manner (Figure 4b). Despite this pattern, for LP, statistically significant differences from the CTL $(F(5,30)=13.37 ; p \leq 0.05)$ were observed only at the highest a.i. concentrations (26 and $40 \mathrm{mg} \mathrm{kg}^{-1}$ ).

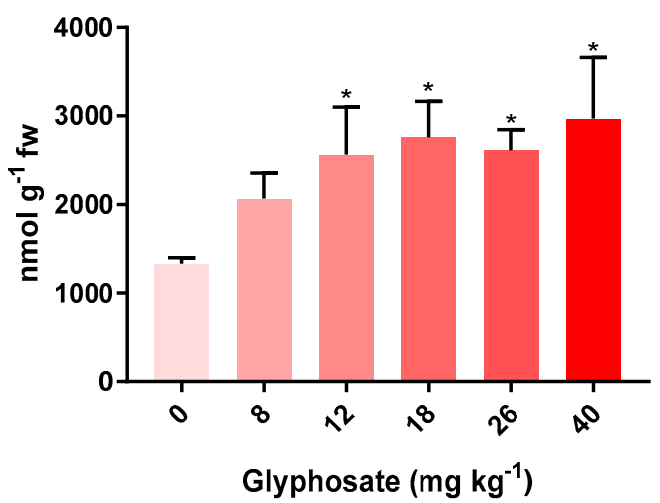

(a)

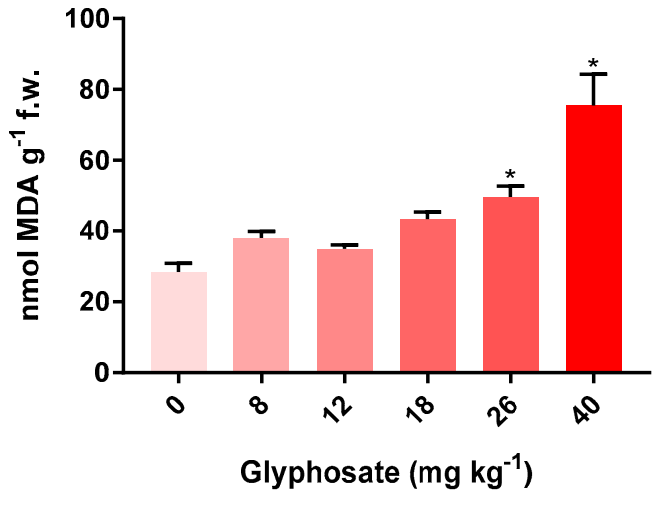

(b)

Figure 4. Average concentrations of $\mathrm{H}_{2} \mathrm{O}_{2}$ (a) and malondialdehyde (MDA) (b) in shoots of M. sativa plants 21 days after exposure to increased concentrations of GLY. Error bars correspond to the standard deviation. Statistically significant differences compared to the CTL, considering $p \leq 0.05$, are marked with a * above bars. 
The AOX response, evaluated by assessing the TAC, total phenol content (TPC) and Pro levels, of M. sativa exposed to Roundup UltraMax ${ }^{\circledR}$ is presented in Figure 5. Regarding TAC (Figure 5a), although a tendency for enhanced values as the concentration of the GBH goes up, statistically significant differences $(F(5,14)=3.468 ; p \leq 0.05)$ were only found when plants were exposed to $40 \mathrm{mg} \mathrm{kg}^{-1}$ of a.i., with an increase of about $75 \%$ above the CTL. On the other hand, TPC (Figure $5 b$ ) was reduced upon exposure to increased concentrations of the GBH, especially in the highest dose (decreases up to $36 \%$ ). Indeed, significant differences $(\mathrm{F}(5,13)=7.802 ; p \leq 0.05)$ compared to the control were observed only for the higher concentration. Concerning Pro (Figure $5 \mathrm{c}$ ), its content showed a similar pattern to that of TAC, with levels significantly higher $(\mathrm{F}(5,8)=5.574 ; p \leq 0.05)$ than the CTL (by threefold) only for the highest concentration of GLY.

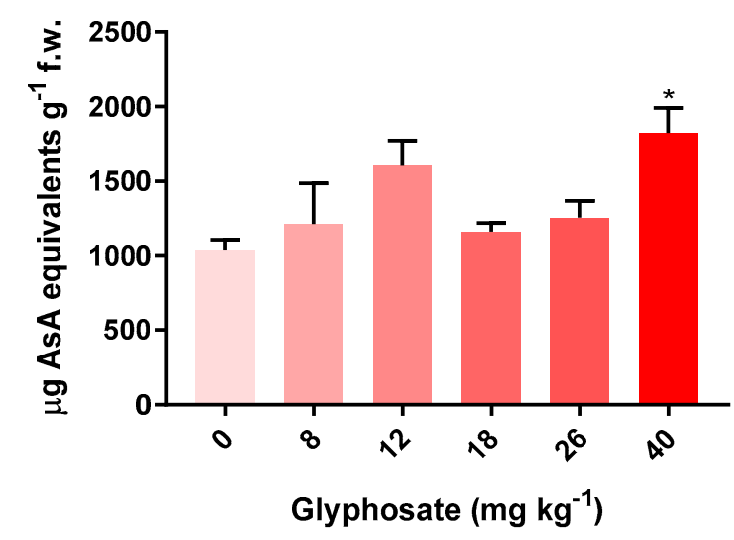

(a)

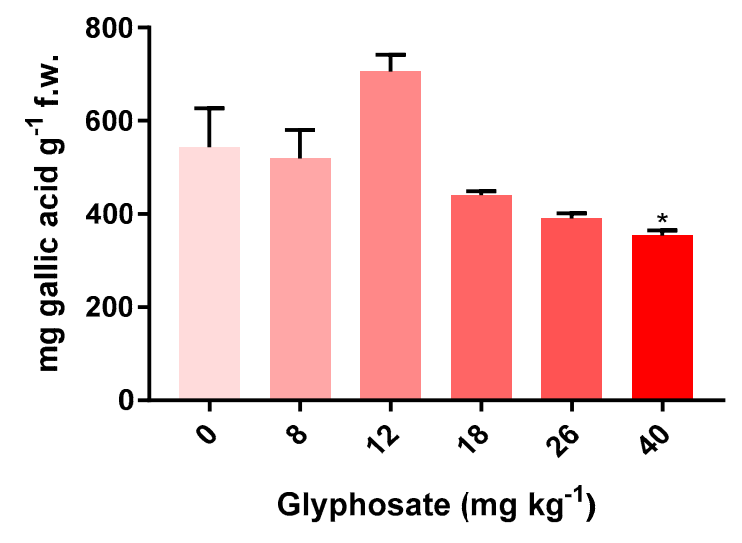

(b)

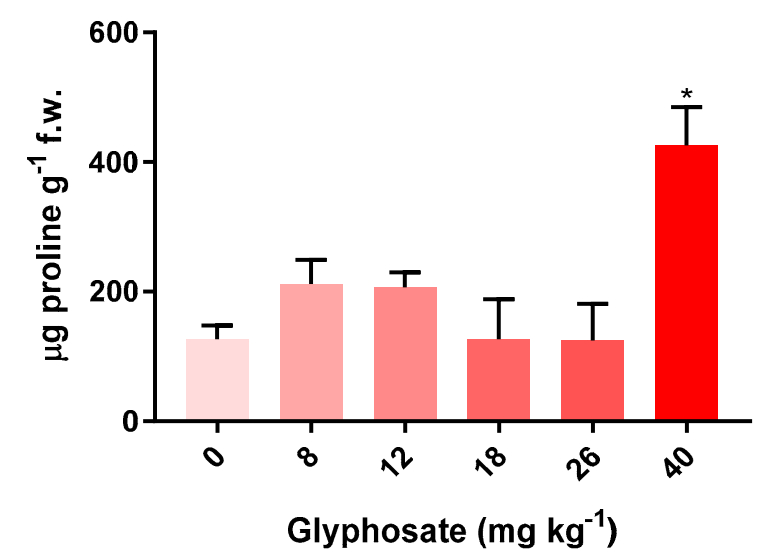

(c)

Figure 5. Effect of increased concentrations of GLY, on the AOX (antioxidant) system of M. sativa shoots after 21 days of exposure. (a) Total antioxidant capacity (TAC); (b) Total phenol content (TPC); (c) Proline (Pro). Error bars correspond to the standard deviation. Statistically significant differences compared to the CTL, considering $p \leq 0.05$, are marked with a * above bars.

\section{Discussion}

To date, little is known regarding the phytotoxicity of GLY-contaminated soils on non-target plants, including cover crop species, such as $M$. sativa. Although these plants are not intentionally treated with GLY, they can still be affected by its application through leaching, runoffs or even wind in the case of spraying. Moreover, GLY strongly adsorbs to solid particles [13,14] and accumulates in soils [15], resulting in a serious problem of diffuse contamination. Indeed, several studies were 
conducted in order to determine GLY levels in soils around the world and despite many of them reporting levels lower than $3 \mathrm{mg} \mathrm{kg}^{-1}$ for agricultural soils or soil located nearby agricultural areas in South America [13,40-42] and Europe [7,43-46], other studies have reported values of $5.0 \mathrm{mg} \mathrm{kg}^{-1}$ in soybean-cultivated areas in Argentina [47], reaching concentrations as high as $40.6 \mathrm{mg} \mathrm{kg}^{-1}$ in olive groves from Greece [45] or even $608 \mathrm{mg} \mathrm{kg}^{-1}$ in a crop fields from Mexico [48]. Therefore, the main goal of the present study was to assess the effects of soil contamination by a GBH on the growth responses and redox homeostasis of alfalfa plants, at environmentally relevant concentrations of the a.i. In fact, despite recent studies having been conducted to evaluate the effects of GLY application in non-target plants, most of these works applied GLY as foliar spray [49-55] or as a supplement to the nutrient solution [12,56-60] rather than simulating soil contamination scenarios.

The present study showed that, after 21 days of exposure, Roundup UltraMax ${ }^{\circledR}$ severely repressed the growth of $M$. sativa in a dose-dependent manner, inhibiting both organ elongation and biomass production. Actually, given the already accentuated reduction in shoot fresh weight upon exposure to the lowest concentration tested $\left(8 \mathrm{mg} \mathrm{kg}^{-1}\right.$ of a.i.), it can be suggested that even lower levels would be capable of impairing plant growth. When GLY is absorbed by the plant, it is translocated through vascular tissues, namely by phloem, reaching active metabolite sites, such as root and shoot meristems, following the same pathway as photoassimilates $[18,61]$, which could explain the repression of shoot growth. The fact that GLY is an herbicide that inhibits an enzyme from the shikimate pathway, 5-enolpyruvylshikimate-3-phosphate synthase (EPSPS; EC 2.5.1.19), can also explain the results obtained. EPSPS plays a role in the synthesis of the aromatic amino acids tryptophan, phenylalanine, and tyrosine that are crucial for the growth and survival of plants and which function as the precursors of many secondary metabolites, such as pigments, auxins and lignin [62]. As a result of the shikimic acid pathway being blocked, there will be an accumulation of shikimate in plant tissues, which will lead to a deficit in important end products, such as lignin, alkaloids and flavonoids, and a reduction in $\mathrm{CO}_{2}$ fixation and biomass production in a dose-dependent manner [63]. The decrease in root and shoot length and biomass can also be due to the impact that GLY has on i) indole-3-acetic-acid (IAA) metabolism which is the main endogenous auxin in the plant, as well as on ii) the interference with plant-water relationships $[30,58,64]$. Another hypothesis that can explain these results is the fact that GLY can impair the absorption of several macro and micronutrients, such as $\mathrm{Ca}, \mathrm{Mg}, \mathrm{N}, \mathrm{P}, \mathrm{Fe}$ and $\mathrm{Zn}$, among others, as reviewed by Gomes et al. [18].

Several studies were conducted in order to evaluate the phytotoxicity of GLY to non-target plants, such as: Pisum sativum (GLY or GBH, applied directly to the seeds or supplemented to the nutrient solution) [55,58]; Hordeum vulgare (GBH supplemented to a mixture of perlite:vermiculite (1:2)) [65]; Solanum lycopersicum (GLY applied by foliar spray) [54]; Vigna radiata (seeds treated with a GBH) [66]; Fagopyrum esculentum (GLY isopropylamine salt supplemented to the nutrient solution) [67]; Lemna minor (GBH supplemented to the nutrient solution) [68]; Dimorphandra wilsonii (seeds treated with a GBH or analytical grade glyphosate) [12]. Even though the experimental conditions of the previously mentioned studies were not similar to the present study, they all recorded a decrease in plant growth, demonstrating the negative effect that both GLY and GBH have on biometric indicators. Concerning GBH-contaminated soils, a similar decrease was also observed in the work of Soares et al. [30], in which tomato plants grew in an artificial soil contaminated by increasing a.i. concentrations $(0,10,20$ and $30 \mathrm{mg} \mathrm{kg}^{-1}$ ). Their results showed significant statistical differences even at $10 \mathrm{mg} \mathrm{kg}^{-1}$, a concentration pretty much identical to the lowest dose tested in this study.

Photosynthesis, one of the main biochemical processes occurring in photoautotrophic organisms, highly depends on light absorption by chlorophylls and carotenoids. The biosynthesis of these pigments, as well as fatty acids or amino acids, can be affected by GLY exposure [69]. As GLY is an EPSPS competitive inhibitor, it blocks the shikimate pathway, thus compromising the biosynthesis of secondary metabolites, such as quinones and photosynthetic pigments, all compounds involved in the photosynthetic metabolism [70]. Previous studies showed that GLY can impair plastoquinone synthesis, thereby contributing to a lower production of carotenoid precursors [50]. Regarding chlorophylls, 
both GLY and GBH can also directly inhibit its biosynthesis, by reducing $\delta$-aminolevulinic acid (ALA) levels, or increase chlorophyll degradation, as reported by several authors $[50,55,71-74]$. Based on these results, it was expected that we would observe a significant decrease in the levels of both chlorophylls and carotenoids. Indeed, even a previous work conducted with the same plant species but grown in perlite and quartz sand [75] reported that the foliar application of a GBH resulted in a reduction in the total photosynthetic pigments as the a.i. concentration increased. However, in the present study, the herbicide showed no effects on chlorophyll and carotenoid contents, despite the slightly lower contents observed when compared to the control group (except for $12 \mathrm{mg} \mathrm{kg}^{-1}$ ). Thus, these results suggest that, at the tested doses, this herbicide did not negatively affect the photosynthetic pigments as also demonstrated in the study performed by Spormann et al. [65] with a GLY concentration of $30 \mathrm{mg} \mathrm{kg}^{-1}$, applied in the form of Roundup UltraMax ${ }^{\circledR}$ and using a mixture of perlite:vermiculite as substrate. As discussed by Spormann et al. [65], these results could be explained by the lack of (aminomethylphosphonic acid) AMPA production in the artificial medium. Indeed, AMPA, the main metabolite formed upon GLY degradation, is considered as a potent phytotoxin, capable of competing with glycine and consequently inhibiting chlorophyll biosynthesis $[76,77]$. Thus, there are two hypotheses for the lack of negative effects due to GLY exposure on chlorophyll and carotenoid content: (i) the use of a standard artificial soil with low microbial activity, not allowing enough AMPA production to cause negative effects on biosynthesis of these pigments; (ii) the mode of application of GLY, which, in this study, was added to the soil contrasting to the majority of works which provided GLY as foliar spray. However, and regarding the former hypothesis, this does not mean that an enhanced effect on a natural soil with a more diverse and functionally active soil microbial community would certainly be expected, as the degradation rates of both GLY and AMPA are still not well studied.

As important as photosynthesis, the mineral nutrition of plants highly contributes to proper growth performance. However, the effect of GLY on plant mineral nutrition is yet to be fully understood [78]. Up to now, no consensus has been reached on the influence that GLY may bring on nutrient uptake, since the studies conducted so far point towards different result. While several authors reported a negative effect of GBH on plant's nutrient uptake [72,78-80], other studies concluded that this application does not affect the mineral status of the plants [81-83]. As reviewed by Duke et al. [83], these inconsistent results may be due to differences in the type of soil, climatic conditions, and/or GLY-resistant cultivars used. Aiming to assess the nutritional status of M. sativa under GLY exposure, the present study evaluated the activity of GS, an enzyme that is involved in the first step of ammonium $\left(\mathrm{NH}^{+}\right)$assimilation, not only that which is absorbed by roots, but also the one generated from photorespiration, proteolysis and processes that are increased by several stresses $[84,85]$. The results revealed that GS was dysregulated for almost all tested concentrations, indicating that, at least under the experimental conditions of the present work, GBH interfered with nitrogen (N) metabolism. Based on these findings, the hypothesis that GLY conditioned the physiological uptake of mineral nutrients, especially nitrogen $(\mathrm{N})$, due to the formation of complexes making them unavailable for biological processes, arises [86]. Concerning $\mathrm{N}$ uptake, once again, results from different studies, all of them using GBH, are contradictory with no effect in field studies $[87,88]$ and inconsistencies in greenhouse studies [78,79].

As previously reviewed by Gill and Tuteja [22] and Soares et al. [20], plant development can be severely affected by various abiotic stressors, such as herbicide application, leading to an overproduction of ROS which, in its turn, will cause significant damage to cell structures, ultimately resulting in oxidative stress. In order to verify the occurrence of oxidative stress, $\mathrm{H}_{2} \mathrm{O}_{2}$ levels and LP degree, as a means to assess membrane damage, were evaluated. According to the results obtained, $\mathrm{H}_{2} \mathrm{O}_{2}$ accumulation was enhanced upon exposure to GBH, especially at levels of the a.i. higher than $12 \mathrm{mg} \mathrm{kg}^{-1}$. However, when looking to LP results, MDA content was only increased in response to the two highest treatments ( 26 and $40 \mathrm{mg} \mathrm{kg}^{-1}$ of a.i.). Based on this behavior, one can suggest that ROS overproduction took place earlier than the observed membrane damage, this being possibly related 
to the dual role played by ROS in plant cells. Indeed, $\mathrm{H}_{2} \mathrm{O}_{2}$, as with other ROS, can act as a signal molecule at low concentrations as it is involved in acclimation signaling, leading to plant tolerance to various biotic and abiotic stresses, becoming toxic above a certain threshold, capable of inducing programmed cell death [89]. Therefore, it can be hypothesized that, at lower GLY concentrations, $\mathrm{H}_{2} \mathrm{O}_{2}$ was involved in signaling mechanisms (with no LP increase), while at the highest concentrations (26 and $40 \mathrm{mg} \mathrm{kg}^{-1}$ of the a.i.), $\mathrm{H}_{2} \mathrm{O}_{2}$ accumulation started to induce oxidative damage, which is reflected by the occurrence of LP.

The induction of oxidative stress by GLY is described as one of its indirect effects on plant physiology, either by the overproduction of ROS or by a depletion of defense mechanisms [50]. Although not so explored as in target and resistant species, the influence of this herbicide on the redox status of non-target plants, including crops, willow and aquatic plants [30,49-52,54,55,65,86,90,91] is starting to gain attention. Corroborating the results of the present work, several studies reported an increase in $\mathrm{H}_{2} \mathrm{O}_{2}$ content and MDA levels in plants grown in GBH-contaminated solid substrate [65], or when GLY or GBH was supplied in nutrient solutions [50,52,55,90], or applied as foliar spray [49,51,54]. However, according to Moldes et al. [91] and Soares et al. [30], the exposure of soybean and tomato plants to GBH did not induce severe oxidative damage in leaves.

In order to defend themselves from oxidative damage caused by ROS, plants developed protective mechanisms by synthetizing enzymatic and non-enzymatic antioxidants [22]. In the context of this work, TAC, TPC and Pro levels were measured to assess the involvement of the non-enzymatic component of the AOX system in limiting GLY-induced stress. The results showed an increase in TAC and Pro levels only at the highest a.i. concentration $\left(40 \mathrm{mg} \mathrm{kg}^{-1}\right)$. Since TAC gives a general idea regarding the cell's AOX status [92] and Pro acts as a strong AOX [22], the elevated TAC and Pro levels suggest that the AOX defense mechanisms were activated due to oxidative stress, but only at the highest concentrations of GLY. Thus, it can be hypothesized that M. sativa plants boosted the accumulation of Pro, along with other non-enzymatic players, to counteract the induced oxidative stress by this herbicide; however, bearing in mind that LP remained higher at the two highest concentrations, this response was not enough to counteract the harmful effects observed. Moreover, phenolic compounds, which are known to chelate metals, scavenge ROS and inhibit LP [93], were negatively affected by the presence of the herbicide, since reduced levels of these specialized metabolites were found in treated plants. This effect probably arises as a consequence of GLY-induced impairment of the shikimate pathway, once phenolic compounds are formed through this biosynthetic process [94], and is in accordance with the results obtained for LP.

Up to now, some studies were conducted in order to evaluate the AOX defense mechanisms of plant species exposed to both GLY and GBH $[30,52,54,65,95]$. These studies demonstrate that there is a dysregulation of the AOX defense system, with records of both increases and decreases in these mechanisms. Particularly, in the study of Soares et al. [30], performed with GBH-contaminated soils, it was observed that this formulation stimulated the AOX defense mechanisms of tomato shoots, at concentrations of 20 and $30 \mathrm{mg} \mathrm{kg}^{-1}$ of the a.i. This suggests that, like other environmental stresses, the response to herbicide application depends on several factors, such as the plant species, the concentration, and the mode of application. However, the results obtained in the present study are in line with those already published by other authors $[30,52,54,65]$ indicating that the increase in Pro levels seems to be the most consistent signal of the activation of the AOX defense against GLY-induced stress, suggesting that this amino acid can be used as a biomarker of exposure to GLY.

\section{Conclusions}

Overall, it is possible to conclude that, after 21 days of exposure to a GBH, the growth and physiological performance of $M$. sativa, were negatively affected at the concentrations tested. The results also showed an activation of the AOX system, although its action was not enough to counteract the oxidative damage induced by an overproduction of ROS, ultimately leading to a decrease in this plant's growth. In the present work, adverse effects of GLY are visible at $8 \mathrm{mg} \mathrm{kg}^{-1}$ of the a.i., which 
is a concentration much lower than the highest levels reported for European and South American soils. However, it should be noted that soil properties, such as soil organic matter content, may affect the behavior of GLY on soils. In addition, the type of formulation can also affect the toxicity, since the presence of surfactants may enhance the negative effects of the a.i. Thus, considering that plant responses to GLY can be species-specific and vary with distinct experimental conditions, it is of upmost importance to better understand the impacts of GLY-contaminated soils on the survival of non-target plants and subsequently on soil biodiversity, as well as developing new strategies to minimize its potential risks to agroecosystems.

Author Contributions: Conceptualization, C.S., R.P. and A.C.; methodology, C.S., F.F., R.P. and A.C.; software, B.F. and C.S.; validation, F.F., R.P. and A.C.; formal analysis, C.S., B.F. and A.C.; investigation, C.B., A.R., R.F., J.F., C.S. and B.F.; resources, F.F. and R.P.; writing-original draft preparation, B.F., C.S. and A.C.; writing-review and editing, F.F. and R.P.; visualization, B.F., C.S. and A.C.; supervision, F.F., R.P. and A.C.; funding acquisition, F.F., R.P. and A.C. All authors have read and agreed to the published version of the manuscript.

Funding: This research was funded by Fundação para a Ciência e a Tecnologia (MEC) and European Regional Development Fund (PT2020 Partnership Agreement), through the Strategic Funding UID/Multi/04423/2019 (CIIMAR), UIDB/05748/2020 and UIDP/05748/2020 (GreenUPorto), and individual grants SFRH/BD/115643/2016 (C.S.) and CEECIND/00058/2017 (A.C.).

Conflicts of Interest: The authors declare no conflict of interest.

\section{References}

1. Pimentel, D. Amounts of pesticides reaching target pests: Environmental impacts and ethics. J. Agric. Environ. Ethics 1995, 8, 17-29. [CrossRef]

2. Duke, S.O. Pesticide Dose - A Parmeter with Many Implications; American Chemical Society: Washington, DC, USA, 2017.

3. Aktar, W.; Sengupta, D.; Chowdhury, A. Impact of pesticides use in agriculture: Their benefits and hazards. Interdiscip. Toxicol. 2009, 2, 1-12. [CrossRef]

4. Imfeld, G.; Vuilleumier, S. Measuring the effects of pesticides on bacterial communities in soil: A critical review. Eur. J. Soil Biol. 2012, 49, 22-30. [CrossRef]

5. Mahmood, I.; Imadi, S.R.; Shazadi, K.; Gul, A.; Hakeem, K.R. Effects of Pesticides on Environment. In Plant, Soil Microbes; Springer: Cham, Switzerland, 2016; pp. 253-269. [CrossRef]

6. Prashar, P.; Shah, S. Impact of Fertilizers and Pesticides on Soil Microfl ora in Agriculture. Sustain. Agric. Rev. 2016, 19, 331-361. [CrossRef]

7. Silva, V.; Mol, H.G.J.; Zomer, P.; Tienstra, M.; Ritsema, C.J.; Geissen, V. Pesticide residues in European agricultural soils-A hidden reality unfolded. Sci. Total Environ. 2019, 653, 1532-1545. [CrossRef]

8. Benbrook, C.M. Trends in glyphosate herbicide use in the United States and globally. Environ. Sci. Eur. 2016, 28, 1-15. [CrossRef]

9. Pochron, S.; Simon, L.; Mirza, A.; Littleton, A.; Sahebzada, F.; Yudell, M. Glyphosate but not Roundup ${ }^{\circledR}$ harms earthworms (Eisenia fetida). Chemosphere 2020, 241, 125017. [CrossRef]

10. Van Bruggen, A.H.C.; He, M.M.; Shin, K.; Mai, V.; Jeong, K.C.; Finckh, M.R.; Morris, J.G. Environmental and health effects of the herbicide glyphosate. Sci. Total Environ. 2018, 616, 255-268. [CrossRef]

11. Mesnage, R.; Benbrook, C.; Antoniou, M.N. Insight into the confusion over surfactant co-formulants in glyphosate-based herbicides. Food Chem. Toxicol. 2019, 128, 137-145. [CrossRef]

12. Gomes, M.P.; da Silva Cruz, F.V.; Bicalho, E.M.; Borges, F.V.; Fonseca, M.B.; Juneau, P.; Garcia, Q.S. Effects of glyphosate acid and the glyphosate-commercial formulation (Roundup) on Dimorphandra wilsonii seed germination: Interference of seed respiratory metabolism. Environ. Pollut. 2017, 220, 452-459. [CrossRef]

13. Aparicio, V.C.; De Gerónimo, E.; Marino, D.; Primost, J.; Carriquiriborde, P.; Costa, J.L. Environmental fate of glyphosate and aminomethylphosphonic acid in surface waters and soil of agricultural basins. Chemosphere 2013, 93, 1866-1873. [CrossRef] [PubMed]

14. Bento, C.P.M.; Goossens, D.; Rezaei, M.; Riksen, M.; Mol, H.G.J.; Ritsema, C.J.; Geissen, V. Glyphosate and AMPA distribution in wind-eroded sediment derived from loess soil. Environ. Pollut. 2017, 220, 1079-1089. [CrossRef] [PubMed] 
15. Bento, C.P.M.; Yang, X.; Gort, G.; Xue, S.; van Dam, R.; Zomer, P.; Mol, H.G.J.; Ritsema, C.J.; Geissen, V. Persistence of glyphosate and aminomethylphosphonic acid in loess soil under different combinations of temperature, soil moisture and light/darkness. Sci. Total Environ. 2016, 572, 301-311. [CrossRef] [PubMed]

16. Herrmann, K.M.; Weaver, L.M. The Shikimate Pathway. Annu. Rev. Plant Physiol. Plant Mol. Biol. 1999, 50, 473-503. [CrossRef]

17. Zabalza, A.; Orcaray, L.; Fernández-Escalada, M.; Zulet-González, A.; Royuela, M. The pattern of shikimate pathway and phenylpropanoids after inhibition by glyphosate or quinate feeding in pea roots. Pestic. Biochem. Physiol. 2017, 141, 96-102. [CrossRef]

18. Gomes, M.P.; Smedbol, E.; Chalifour, A.; Hénault-Ethier, L.; Labrecque, M.; Lepage, L.; Lucotte, M.; Juneau, P. Alteration of plant physiology by glyphosate and its by-product aminomethylphosphonic acid: An overview. J. Exp. Bot. 2014, 65, 4691-4703. [CrossRef]

19. Choudhury, S.; Panda, P.; Sahoo, L.; Panda, S.K. Reactive oxygen species signaling in plants under abiotic stress. Plant Signal. Behav. 2013, 8. [CrossRef]

20. Soares, C.; Carvalho, M.E.A.; Azevedo, R.A.; Fidalgo, F. Plants facing oxidative challenges-A little help from the antioxidant networks. Environ. Exp. Bot. 2019, 4-25. [CrossRef]

21. Soares, C.; Branco-Neves, S.; de Sousa, A.; Pereira, R.; Fidalgo, F. Ecotoxicological relevance of nano-NiO and acetaminophen to Hordeum vulgare L.: Combining standardized procedures and physiological endpoints. Chemosphere 2016, 165, 442-452. [CrossRef]

22. Gill, S.S.; Tuteja, N. Reactive oxygen species and antioxidant machinery in abiotic stress tolerance in crop plants. Plant Physiol. Biochem. 2010, 48, 909-930. [CrossRef]

23. Wittwer, R.A.; Dorn, B.; Jossi, W.; Van Der Heijden, M.G.A. Cover crops support ecological intensification of arable cropping systems. Sci. Rep. 2017, 7, 1-12. [CrossRef] [PubMed]

24. Büchi, L.; Wendling, M.; Amossé, C.; Necpalova, M.; Charles, R. Importance of cover crops in alleviating negative effects of reduced soil tillage and promoting soil fertility in a winter wheat cropping system. Agric. Ecosyst. Environ. 2018, 256, 92-104. [CrossRef]

25. European Commission Sustainable Land Use (Greening). Available online: https://ec.europa.eu/info/foodfarming-fisheries/key-policies/common-agricultural-policy/income-support/greening_en\#documents (accessed on 20 May 2020).

26. Hamdi, H.; Benzarti, S.; Aoyama, I.; Jedidi, N. Rehabilitation of degraded soils containing aged PAHs based on phytoremediation with alfalfa (Medicago sativa L.). Int. Biodeterior. Biodegrad. 2012, 67, 40-47. [CrossRef]

27. Gamal Hassouna, M.; Thanaa Hassan, M.; Ahmad Madkour, M. Increased yields of alfalfa (Medicago sativa) inoculated with n2-fixing bacteria and cultivated in a calcareous soil of northwestern egypt. Arid Soil Res. Rehabil. 1994, 8, 389-393. [CrossRef]

28. Zhu, R.F.; Tang, F.L.; Liu, J.L.; Liu, F.Q.; Deng, X.Y.; Chen, J.S. Co-inoculation of arbusculr mycorrhizae and nitrogen fixing bacteria enhance alfalfa yield under saline conditions. Pak. J. Bot. 2016, 48, 763-769. [CrossRef]

29. OECD. OECD 207-Earthworm, Acute Toxicity Tests. In OECD Guidelines for the Testing of Chemicals Section 2; OECD: Paris, France, 1984; Volume 207, p. 9. [CrossRef]

30. Soares, C.; Pereira, R.; Spormann, S.; Fidalgo, F. Is soil contamination by a glyphosate commercial formulation truly harmless to non-target plants?-Evaluation of oxidative damage and antioxidant responses in tomato. Environ. Pollut. 2019, 247, 256-265. [CrossRef]

31. Soares, C.; Pereira, R.; Martins, M.; Tamagnini, P.; Serôdio, J.; Moutinho-Pereira, J.; Cunha, A.; Fidalgo, F. Glyphosate-dependent effects on photosynthesis of Solanum lycopersicum L.-An ecophysiological, ultrastructural and molecular approach. J. Hazard. Mater. 2020, 398, 122871. [CrossRef]

32. OCDE. 208-Terrestrial Plant Test: Seedling Emergence and Seedling Growth Test. In OECD Guidelines for the Testing of Chemicals Section 2; OECD: Paris, France, 2006; Volume 227, pp. 1-21. [CrossRef]

33. Lichtenthaler, H.K. Chlorophylls and Carotenoids: Pigments of Photosynthetic Biomembranes. Methods Enzymol. 1987, 148, 350-382. [CrossRef]

34. Bradford, M.M. A Rapid and Sensitive Method for the Quantification of Microgram Quantities of Protein Utilizing the Principle of Protein-Dye Binding. Anal. Biochem. 1976, 72, 248-254. [CrossRef]

35. Ferguson, A.R.; Sims, A.P. Inactivation In vivo of Glutarnine Synthetase and NAD-specific Glutamate Dehydrogenase: Its Role in the Regulation of Glutamine Synthesis in Yeasts. J. Gen. Microbiol. 1971, 69, 423-427. [CrossRef] 
36. Heath, R.L.; Packer, L. Photoperoxidation in isolated chloroplasts. Arch. Biochem. Biophys. 1968, 125, $189-198$. [CrossRef]

37. Jana, S.; Choudhuri, M.A. Glycolate metabolism of three submersed aquatic angiosperms: Effect of heavy metals. Aquat. Bot. 1981, 12, 345-354. [CrossRef]

38. Zafar, H.; Ali, A.; Ali, J.S.; Haq, I.U.; Zia, M. Effect of ZnO nanoparticles on Brassica nigra seedlings and stem explants: Growth dynamics and antioxidative response. Front. Plant Sci. 2016, 7, 535. [CrossRef] [PubMed]

39. Bates, L.S.; Waldren, R.P.; Teare, I.D. Rapid determination of free proline for water-stress studies. Plant Soil 1973, 39, 205-207. [CrossRef]

40. Primost, J.E.; Marino, D.J.G.; Aparicio, V.C.; Costa, J.L.; Carriquiriborde, P. Glyphosate and AMPA, "pseudo-persistent" pollutants under real-world agricultural management practices in the Mesopotamic Pampas agroecosystem, Argentina. Environ. Pollut. 2017, 229, 771-779. [CrossRef] [PubMed]

41. Alonso, L.L.; Demetrio, P.M.; Agustina Etchegoyen, M.; Marino, D.J. Glyphosate and atrazine in rainfall and soils in agroproductive areas of the pampas region in Argentina. Sci. Total Environ. 2018, 645, 89-96. [CrossRef]

42. Soracco, C.G.; Villarreal, R.; Lozano, L.A.; Vittori, S.; Melani, E.M.; Marino, D.J.G. Glyphosate dynamics in a soil under conventional and no-till systems during a soybean growing season. Geoderma 2018, 323, $13-21$. [CrossRef]

43. Grunewald, K.; Schmidt, W.; Unger, C.; Hanschmann, G. Behavior of glyphosate and aminomethylphosphonic acid (AMPA) in soils and water of reservoir Radeburg II catchment (Saxony/Germany). J. Plant Nutr. Soil Sci. 2001, 164, 65-70. [CrossRef]

44. Laitinen, P.; Siimes, K.; Eronen, L.; Rämö, S.; Welling, L.; Oinonen, S.; Mattsoff, L.; Ruohonen-Lehto, M. Fate of the herbicides glyphosate, glufosinate-ammonium, phenmedipham, ethofumesate and metamitron in two Finnish arable soils. Pest Manag. Sci. 2006, 62, 473-491. [CrossRef]

45. Karanasios, E.; Karasali, H.; Marousopoulou, A.; Akrivou, A.; Markellou, E. Monitoring of glyphosate and AMPA in soil samples from two olive cultivation areas in Greece: Aspects related to spray operators activities. Environ. Monit. Assess. 2018, 190. [CrossRef]

46. Silva, V.; Montanarella, L.; Jones, A.; Fernández-ugalde, O.; Mol, H.G.J.; Ritsema, C.J.; Geissen, V. Distribution of glyphosate and aminomethylphosphonic acid (AMPA) in agricultural topsoils of the European Union. Sci. Total Environ. 2018, 621, 1352-1359. [CrossRef] [PubMed]

47. Peruzzo, P.J.; Porta, A.A.; Ronco, A.E. Levels of glyphosate in surface waters, sediments and soils associated with direct sowing soybean cultivation in north pampasic region of Argentina. Environ. Pollut. 2008, 156, 61-66. [CrossRef] [PubMed]

48. Muñoz, R.; Guevara-Lara, A.; Santos, J.L.M.; Miranda, J.M.; Rodriguez, J.A. Determination of glyphosate in soil samples using CdTe/CdS quantum dots in capillary electrophoresis. Microchem. J. 2019, 146, 582-587. [CrossRef]

49. Akbulut, G.B.; Yigit, E.; Bayram, D. Investigation of the Effects of Salicylic Acid on Some Biochemical Parameters in Zea mays to Glyphosate Herbicide. J. Environ. Anal. Toxicol. 2015, 5, 1-9. [CrossRef]

50. Gomes, M.P.; Le Manac'h, S.G.; Maccario, S.; Labrecque, M.; Lucotte, M.; Juneau, P. Differential effects of glyphosate and aminomethylphosphonic acid (AMPA) on photosynthesis and chlorophyll metabolism in willow plants. Pestic. Biochem. Physiol. 2015. [CrossRef]

51. Radwan, D.E.M.; Fayez, K.A. Photosynthesis, antioxidant status and gas-exchange are altered by glyphosate application in peanut leaves. Photosynthetica 2016, 54, 307-316. [CrossRef]

52. Gomes, M.P.; Le Manac'h, S.G.; Hénault-Ethier, L.; Labrecque, M.; Lucotte, M.; Juneau, P. Glyphosate-dependent inhibition of photosynthesis in willow. Front. Plant Sci. 2017, 8, 1-13. [CrossRef]

53. Krenchinski, F.H.; Albrecht, L.P.; Albrecht, A.J.P.; Cesco, V.J.S.; Rodrigues, D.M.; Portz, R.L.; Zobiole, L.H.S. Glyphosate affects chlorophyll, photosynthesis and water use of four Intacta RR2 soybean cultivars. Acta Physiol. Plant. 2017, 39, 1-13. [CrossRef]

54. Singh, H.; Singh, N.B.; Singh, A.; Hussain, I. Exogenous Application of Salicylic Acid to Alleviate Glyphosate Stress in Solanum lycopersicum. Int. J. Veg. Sci. 2017, 23, 552-566. [CrossRef]

55. Singh, H.; Singh, N.B.; Singh, A.; Hussain, I.; Yadav, V. Physiological and biochemical roles of nitric oxide against toxicity produced by glyphosate herbicide in Pisum sativum. Russ. J. Plant Physiol. 2017, 64, 518-524. [CrossRef] 
56. De Campos Oliveira, R.; Boas, L.K.V.; Branco, C.C.Z. Assessment of the potential toxicity of glyphosate-based herbicides on the photosynthesis of Nitella microcarpa var. wrightii (Charophyceae). Phycologia 2016, 55, 577-584. [CrossRef]

57. de Freitas-Silva, L.; Rodríguez-Ruiz, M.; Houmani, H.; da Silva, L.C.; Palma, J.M.; Corpas, F.J. Glyphosate-induced oxidative stress in Arabidopsis thaliana affecting peroxisomal metabolism and triggers activity in the oxidative phase of the pentose phosphate pathway (OxPPP) involved in NADPH generation. J. Plant Physiol. 2017, 218, 196-205. [CrossRef] [PubMed]

58. Mondal, S.; Kumar, M.; Haque, S.; Kundu, D. Phytotoxicity of glyphosate in the germination of Pisum sativum and its effect on germinated seedlings. Environ. Health Toxicol. 2017, 32, e2017011. [CrossRef] [PubMed]

59. Tong, M.; Gao, W.; Jiao, W.; Zhou, J.; Li, Y.; He, L.; Hou, R. Uptake, Translocation, Metabolism, and Distribution of Glyphosate in Nontarget Tea Plant (Camellia sinensis L.). J. Agric. Food Chem. 2017, 65, 7638-7646. [CrossRef] [PubMed]

60. Serra, A.A.; Couée, I.; Renault, D.; Gouesbet, G.; Sulmon, C. Metabolic profiling of Lolium perenne shows functional integration of metabolic responses to diverse subtoxic conditions of chemical stress. J. Exp. Bot. 2015, 66, 1801-1816. [CrossRef]

61. Satchivi, N.M.; Wax, L.M.; Stoller, E.W.; Briskin, D.P. Absorption and translocation of glyphosate isopropylamine and trimethylsulfonium salts in Abutilon theophrasti and Setaria faberi. Weed Sci. 2000, 48, 675-679. [CrossRef]

62. Herrmann, K.M. The shikimate pathway: Early steps in the biosynthesis of aromatic compounds. Plant Cell 1995, 7, 907-919. [CrossRef]

63. Olesen, C.F.; Cedergreen, N. Glyphosate uncouples gas exchange and chlorophyll fluorescence. Pest Manag. Sci. 2010, 66, 536-542. [CrossRef]

64. Clay, P.A.; Griffin, J.L. Weed seed production and seedling emergence responses to late-season glyphosate applications. Weed Sci. 2000, 48, 481-486. [CrossRef]

65. Spormann, S.; Soares, C.; Fidalgo, F. Salicylic acid alleviates glyphosate-induced oxidative stress in Hordeum vulgare L. J. Environ. Manag. 2019, 241, 226-234. [CrossRef]

66. Basantani, M.; Srivastava, A.; Sen, S. Elevated antioxidant response and induction of tau-class glutathione S-transferase after glyphosate treatment in Vigna radiata (L.) Wilczek. Pestic. Biochem. Physiol. 2011, 99, 111-117. [CrossRef]

67. Debski, H.; Wiczkowski, W.; Szawara-Nowak, D.; Baczek, N.; Chrzanowski, G.; Horbowicz, M. Effects of glyphosate and fluazifop-P-butyl on flavonoids content and growth of common buckwheat (Fagopyrum esculentum Moench). Fresenius Environ. Bull. 2018, 27, 91-97.

68. Sikorski, Ł.; Baciak, M.; Bęś, A.; Adomas, B. The effects of glyphosate-based herbicide formulations on Lemna minor, a non-target species. Aquat. Toxicol. 2019, 209, 70-80. [CrossRef] [PubMed]

69. Fedtke, K.; Duke, S. Herbicides. In Plant Toxicology; Marcel Dekker: New York, NY, USA, 2005.

70. Dewick, P.M. The biosynthesis of shikimate metabolites. Nat. Prod. Rep. 1986, 3, 565-585. [CrossRef]

71. Mateos-Naranjo, E.; Redondo-Gómez, S.; Cox, L.; Cornejo, J.; Figueroa, M.E. Effectiveness of glyphosate and imazamox on the control of the invasive cordgrass Spartina densiflora. Ecotoxicol. Environ. Saf. 2009, 72, 1694-1700. [CrossRef]

72. Zobiole, L.H.S.; Kremer, R.J.; Oliveira, R.S.; Constantin, J. Glyphosate affects chlorophyll, nodulation and nutrient accumulation of "second generation" glyphosate-resistant soybean (Glycine max L.). Pestic. Biochem. Physiol. 2011, 99, 53-60. [CrossRef]

73. Huang, J.; Silva, E.N.; Shen, Z.; Jiang, B.; Lu, H. Effects of glyphosate on photosynthesis, chlorophyll fluorescence and physicochemical propertiesof cogongrass (Imperata cylindrical L.). Plant Omics 2012, 5, 177-183.

74. Kitchen, L.M.; Witt, W.W.; Rieck, C.E. Inhibition of Chlorophyll Accumulation by Glyphosate. Weed Sci. 1981, 29, 513-516. [CrossRef]

75. Muñoz-Rueda, A.; Gonzalez-Murua, C.; Becerril, J.M.; Sánchez-Díaz, M.F. Effects of glyphosate [N-(phosphonomethyl)glycine] on photosynthetic pigments, stomatal response and photosynthetic electron transport in Medicago sativa and Trifolium pratense. Physiol. Plant. 1986, 66, 63-68. [CrossRef]

76. Reddy, K.N.; Rimando, A.M.; Duke, S.O. Aminomethylphosphonic acid, a metabolite of glyphosate, causes injury in glyphosate-treated, glyphosate-resistant soybean. J. Agric. Food Chem. 2004, 52, 5139-5143. [CrossRef] 
77. Serra, A.A.; Nuttens, A.; Larvor, V.; Renault, D.; Couée, I.; Sulmon, C.; Gouesbet, G. Low environmentally relevant levels of bioactive xenobiotics and associated degradation products cause cryptic perturbations of metabolism and molecular stress responses in Arabidopsis thaliana. J. Exp. Bot. 2013, 64, 2753-2766. [CrossRef]

78. Zobiole, L.H.S.; de Oliveira, R.S.; Kremer, R.J.; Muniz, A.S.; de Oliveira, A. Nutrient accumulation and photosynthesis in glyphosate-resistant soybeans is reduced under glyphosate use. J. Plant Nutr. 2010, 33, 1860-1873. [CrossRef]

79. Cakmak, I.; Yazici, A.; Tutus, Y.; Ozturk, L. Glyphosate reduced seed and leaf concentrations of calcium, manganese, magnesium, and iron in non-glyphosate resistant soybean. Eur. J. Agron. 2009, 31, 114-119. [CrossRef]

80. Zobiole, L.H.; Kremer, R.J.; de Oliveira, R.S.; Constantin, J. Glyphosate effects on photosynthesis, nutrient accumulation, and nodulation in glyphosate-resistant soybean. J. Plant Nutr. Soil Sci. 2012, 175, 319-330. [CrossRef]

81. Bailey, W.A.; Poston, D.H.; Wilson, H.P.; Hines, T.E. Glyphosate Interactions with Manganese. Weed Technol. 2002, 16, 792-799. [CrossRef]

82. Duke, S.O.; Reddy, K.N.; Bu, K.; Cizdziel, J. V Effects of Glyphosate on the Mineral Content of Glyphosate-Resistant Soybeans (Glycine max). J. Agric. Food Chem. 2012, 60, 6764-6771. [CrossRef] [PubMed]

83. Duke, S.O.; Lydon, J.; Koskinen, W.C.; Moorman, T.B.; Chaney, R.L.; Hammerschmidt, R. Glyphosate effects on plant mineral nutrition, crop rhizosphere microbiota, and plant disease in glyphosate-resistant crops. J. Agric. Food Chem. 2012, 60, 10375-10397. [CrossRef] [PubMed]

84. Pageau, K.; Reisdorf-Cren, M.; Morot-Gaudry, J.F.; Masclaux-Daubresse, C. The two senescence-related markers, GS1 (cytosolic glutamine synthetase) and GDH (glutamate dehydrogenase), involved in nitrogen mobilization, are differentially regulated during pathogen attack and by stress hormones and reactive oxygen species in Nicoti. J. Exp. Bot. 2006, 57, 547-557. [CrossRef]

85. Gomes Silveira, J.A.; De Almeida Viégas, R.; Almeida Da Rocha, I.M.; De Oliveira Monteiro Moreira, A.C.; De Azevedo Moreira, R.D.; Abreu Oliveira, J.T. Proline accumulation and glutamine synthetase activity are increased by salt-induced proteolysis in cashew leaves. J. Plant Physiol. 2003, 160, 115-123. [CrossRef]

86. Zhong, G.; Wu, Z.; Yin, J.; Chai, L. Responses of Hydrilla verticillata (L.f.) Royle and Vallisneria natans (Lour.) Hara to glyphosate exposure. Chemosphere 2018, 193, 385-393. [CrossRef]

87. Bellaloui, N.; Reddy, K.N.; Zablotowicz, R.M.; Mengistu, A. Simulated glyphosate drift influences nitrate assimilation and nitrogen fixation in non-glyphosate-resistant soybean. J. Agric. Food Chem. 2006, 54, 3357-3364. [CrossRef] [PubMed]

88. Henry, R.S.; Wise, K.A.; Johnson, W.G. Glyphosate's Effect Upon Mineral Accumulation in Soybean. Crop Manag. 2011, 10. [CrossRef]

89. Quan, L.J.; Zhang, B.; Shi, W.W.; Li, H.Y. Hydrogen peroxide in plants: A versatile molecule of the reactive oxygen species network. J. Integr. Plant Biol. 2008, 50, 2-18. [CrossRef] [PubMed]

90. Gomes, M.P.; Juneau, P. Oxidative stress in duckweed (Lemna minor L.) induced by glyphosate: Is the mitochondrial electron transport chain a target of this herbicide? Environ. Pollut. 2016, 218, 402-409. [CrossRef] [PubMed]

91. Moldes, C.A.; Medici, L.O.; Abrahão, O.S.; Tsai, S.M.; Azevedo, R.A. Biochemical responses of glyphosate resistant and susceptible soybean plants exposed to glyphosate. Acta Physiol. Plant. 2008, 30, 469-479. [CrossRef]

92. Pinto, M.; Soares, C.; Pinto, A.S.; Fidalgo, F. Phytotoxic effects of bulk and nano-sized Ni on Lycium barbarum L. grown in vitro-Oxidative damage and antioxidant response. Chemosphere 2019, 218, 507-516. [CrossRef] [PubMed]

93. Sharma, P.; Jha, A.B.; Dubey, R.S.; Pessarakli, M. Reactive Oxygen Species, Oxidative Damage, and Antioxidative Defense Mechanism in Plants under Stressful Conditions. J. Bot. 2012, 2012, 217037. [CrossRef]

94. Santos-Sánchez, N.; Salas-Coronado, R.; Hernández-Carlos, B.; Villanueva-Cañongo, C. Shikimic Acid Pathway in Biosynthesis of Phenolic Compounds. In Plant Physiological Aspects of Phenolic Compounds; Intechopen: London, UK, 2019; pp. 1-15.

95. Sergiev, I.G.; Alexieva, V.S.; Ivanov, S.V.; Moskova, I.I.; Karanov, E.N. The phenylurea cytokinin 4PU-30 protects maize plants against glyphosate action. Pestic. Biochem. Physiol. 2006, 85, 139-146. [CrossRef]

(C) 2020 by the authors. Licensee MDPI, Basel, Switzerland. This article is an open access article distributed under the terms and conditions of the Creative Commons Attribution (CC BY) license (http://creativecommons.org/licenses/by/4.0/). 